J. Dairy Sci. 95:3527-3535

http://dx.doi.org/10.3168/jds.2011-5048

(C) American Dairy Science Association ${ }^{\circledR}, 2012$.

\title{
Effect of reduction of milking frequency and supplementation of vitamin $E$ and selenium above requirements on milk yield and composition in Assaf ewes
}

\author{
E. Pulido, F. J. Giráldez, R. Bodas, S. Andrés, and N. Prieto ${ }^{1}$ \\ Instituto de Ganadería de Montaña (CSIC-ULE), Finca Marzanas s/n, 24346 Grulleros, León, Spain
}

\begin{abstract}
The aim of this research was to study the effect of milking frequency and supplementation with a vitaminmineral complex above requirements on intake, body weight $(\mathrm{BW})$, and milk yield and composition in highyielding Assaf ewes. Sixteen lactating Assaf ewes were used in this study, separated into 4 groups of 4 ewes each. Animals in 2 of the groups (control groups) did not receive any extra vitamin-mineral supplement, whereas animals in the other 2 groups (supplement groups) received daily an oral dose of $1 \mathrm{~g}$ of vitamin $\mathrm{E}(1,000$ IU, DL- $\alpha$-tocopherol acetate) and $0.4 \mathrm{mg}$ of selenium (sodium selenite anhydrous). The experiment consisted of 2 consecutive periods of $3 \mathrm{wk}$ (twice-daily milking in both mammary glands) and 8 wk (once-daily milking in one mammary gland and twice-daily milking in the other gland). Intake, BW, and milk composition were controlled weekly, and milk production was recorded 3 times a week. Administration of the vitamin-mineral supplement had no effect on dry matter intake, BW, or milk production and composition. The reduction of milking from twice to once a day caused a decrease in milk production and lactose concentration and a significant increase in protein concentration, total solids, and somatic cell count, without affecting the fat content. Administration of a vitamin E and Se supplement at the doses used in the present study does not seem to exert, in the short term, a noticeable effect on the mammary gland when milking frequency is reduced.
\end{abstract}

Key words: dairy sheep, milking frequency, antioxidant, milk yield and composition

\section{INTRODUCTION}

Sheep milk is in increasing demand in Europe, especially in the Mediterranean countries, and it is becoming a popular alternative for the manufacture of ex-

Received October 14, 2011.

Accepted February 22, 2012.

${ }^{1}$ Corresponding author: nuria.prieto@eae.csic.es pensive, high-quality dairy products, especially cheeses (Haenlein, 2007). On most farms, sheep are kept in small flocks by the owner and his family, and ewes are generally milked twice a day (once in the morning and once in the evening), with a time interval as near as possible to $12 \mathrm{~h}$. This practice constitutes one of the most important constraints because it does not allow for any break in the farmer's activity; labor during milking represents about $55 \%$ of the total labor input (Marnet and McKusick, 2001). Hence, it is necessary to improve the livelihoods and income levels of small farmers and their families to help them in their enterprises and reduce off-farm migration (Haenlein, 2001).

Any reduction in the number of milkings would undoubtedly represent a significant improvement in the quality of farming life and result in significant savings in labor and expense. Studies performed on the effect of milking frequency reduction on milk yield and its composition show variable and sometimes even contradictory results (Nudda et al., 2002; Hervás et al., 2006; Castillo et al., 2008). This variability in response can be considered an opportunity rather than a problem, because it allows us to propose the establishment of production systems based on one milking with an acceptable milk production and composition. Obviously, to achieve this goal, it is necessary to identify the biological mechanism determining the effect associated with milking frequency and factors that can modulate the response obtained.

Bernier-Dodier et al. (2010) observed that once-daily milking increased mammary cell apoptosis and, surprisingly, mammary cell proliferation. This higher activity, especially of apoptosis, can generate a higher oxidative stress with the accumulation of reactive oxygen species that have been associated with tissue damage in several inflammation models. Indeed, Lauzon et al. (2005) suggested that antioxidants might be effective tools for protecting mammary tissue against neutrophil-induced oxidative stress. Hence, modulating the antioxidant capacity and inflammatory response could also modify the response of the mammary gland to changes in the milking routine. 
It is well known that vitamin $\mathrm{E}$ and selenium are essential micronutrients that share a common biological role as antioxidants because they protect lipid membranes from attack by reactive oxygen species and lipid hydroperoxides (Rice and Kennedy, 1988; Bendich, 1990; Yang et al., 2011). Furthermore, it has been demonstrated that the administration of pharmacological doses of vitamin E might reduce plasma indices of oxidative stress and diverse proinflammatory cytokines (Rizzo et al., 2008). The antioxidant capacity of this vitamin (administrated alone or in combination with Se) has been observed in some studies of dairy cattle and goats on milk production and composition (Politis et al., 2004; Tufarelli and Laudadio, 2011) and on lamb antioxidant status when their dams were supplemented with vitamin E (Capper et al., 2005). However, to the best of our knowledge, no studies have evaluated the effect of both vitamin $\mathrm{E}$ and Se supplementation above requirement in ewes on milk yield and composition. In addition, it is worth noting that no studies have tested the relationship between milking frequency and antioxidant capacity of the organism when milking frequency is modified.

Considering the lack of research evidence, the aim of this work was to study the effect of milking frequency and supplementation of vitamin $\mathrm{E}$ and Se above requirements in high-yielding Assaf ewes on intake, BW, and milk yield and composition.

\section{MATERIALS AND METHODS}

\section{Animals and Diets}

Sixteen high-yielding Assaf ewes in wk 4 of lactation were used in this study, separated into 4 groups of 4 ewes each. The groups were equilibrated according to BW $(77.0 \pm 2.37 \mathrm{~kg})$, milk production $(2,548 \pm 119.7$ $\mathrm{g} / \mathrm{d}$ ), left gland/right gland milk production ratio (1.00 $\pm 0.023)$, day of lactation $(26.6 \pm 1.51 \mathrm{~d})$, and cisternal milk production $(64 \pm 2.6 \%)$. The selected ewes were multiparous and most were in the first lactation.

The experimental treatments were randomly assigned to control groups: 2 groups of animals that did not receive any extra vitamin-mineral supplement), and supplement groups: 2 groups of animals that received a daily oral dose of $1 \mathrm{~g}$ of vitamin $\mathrm{E}$ (DL- $\alpha$-tocopherol acetate, BASF, Burgbernheim, Germany), equivalent to 1,000 IU, and $0.4 \mathrm{mg}$ of Se (sodium selenite anhydrous, Panreac, Barcelona, Spain).

Ewes were managed similarly and maintained under the same feeding system from parturition and throughout the experimental period, based on a TMR supplied ad libitum, whose composition is shown in Table 1. Diet was formulated with the objective of meeting vitamin
Table 1. Ingredients and chemical composition of the TMR

\begin{tabular}{lc}
\hline Item & Value \\
\hline Ingredients (g/kg as fed-basis) & \\
Dehydrated alfalfa & 300 \\
Barley grain & 230 \\
Corn grain & 120 \\
Soybean meal 44 & 80 \\
Oats & 70 \\
Cotton seed & 50 \\
Sugar beet pulp & 40 \\
Rapeseed meal & 30 \\
Sunflower meal & 30 \\
Molasses & 25 \\
Calcium carbonate & 13 \\
Sodium chloride & 5 \\
Wheat shorts & 3 \\
Mineral and vitamins ${ }^{1}$ & 4 \\
Vitamin E (mg/kg) & 8 \\
Selenium (mg/kg) & 0.2 \\
Chemical composition (g/kg, as fed-basis) & \\
DM & 952 \\
CP & 169 \\
Crude fiber & \\
NDF & 140 \\
ADF & 285 \\
Ether extract & 155 \\
Ash & 42 \\
M & 86 \\
\hline
\end{tabular}

${ }^{1}$ Mineral and vitamin premix: vitamin $\mathrm{A}(7,000 \mathrm{IU} / \mathrm{kg})$, vitamin $\mathrm{D}_{3}$ $(1,400 \mathrm{IU} / \mathrm{kg}$ ), copper (copper sulfate pentahydrate) $2 \mathrm{mg} / \mathrm{kg}$, iron (iron sulfate monohydrate) $49 \mathrm{mg} / \mathrm{kg}$, zinc (zinc oxide) $34 \mathrm{mg} / \mathrm{kg}$, manganese (manganese oxide) $32 \mathrm{mg} / \mathrm{kg}$, cobalt (cobalt carbonate monohydrate) $0.9 \mathrm{mg} / \mathrm{kg}$, iodine (potassium iodide) $2 \mathrm{mg} / \mathrm{kg}$.

${ }^{2}$ Estimated crude fiber content.

$\mathrm{E}$ and Se requirements (National Research Council, 1985). Ewes were housed in lots of 4 in neighboring pens, and fresh drinking water was always available for the animals.

The experiment was carried out in accordance with Spanish Royal Decree 1201/2005 for the protection of animals used for experimental and other scientific purposes. The experimental procedures were approved by the Institutional Animal Care and Use Committee of the Instituto de Ganadería de Montaña (CSIC, Spain).

\section{Experimental Procedures}

Two days before the experiment began, each animal was intravenously dosed with an oxytocin antagonist (1 mg/ewe; Atosiban, Hybio Pharmaceutical Co. Ltd., Shenzhen, China) to inhibit the ejection stimulus and determine the fraction of cisternal milk. Subsequently, the fraction of alveolar milk was recovered by means of an intravenous injection of synthetic oxytocin (5 UI/ ewe; Oxitón, Laboratorios Ovejero, León, Spain).

The experiment lasted 11 wk over 2 consecutive periods in which the milking frequency varied: period 1 (3 wk), when ewes were milked twice a day (at 0930 and $1930 \mathrm{~h}$ ) in both mammary glands, and period 2 
( 8 wk), when ewes were unilaterally milked at different frequencies: one milking a day (morning) in one mammary gland and 2 milkings a day (morning and evening) in the other gland. Each milking frequency was randomly assigned to the glands.

During the milking period, ewes were machine milked twice a day at 0830 and $1930 \mathrm{~h}$ in a $1 \times 10$ low-line Casse system milking parlor, with 10 milking units and 2 milkers. The milking machine (Alfa-Laval Iberia S.A., Madrid, Spain) was set to provide 120 pulsations per minute in a 50:50 ratio at a vacuum level of $36 \mathrm{kPa}$. The milking routine for the regular daily milking included teat cleaning, machine stripping (i.e., massaging the udder and pulling down on the cups), and teat dipping (Alfadine, DeLaval, Barcelona, Spain).

\section{Intake and BW}

The TMR was administrated per lot of 4 ewes each once a day after morning milking. The amount of feed offered was adjusted weekly based on the previous week's intake, allowing refusals of approximately $200 \mathrm{~g} / \mathrm{kg}$ of feed offered. The amount of feed refused was withdrawn and weighed once a week and samples were collected to determine DM content. Animals were weighed weekly after milking and before feed administration using a mobile scale (Magriña 102 III, Barcelona, Spain).

\section{Milk Production and Composition}

Milk yield, expressed daily as the sum of morning and evening milkings, was recorded 3 times a week (Monday, Wednesday, and Friday) for each mammary gland. Milk samples from each udder half were taken in milk collection jars every Wednesday at the morning milking or at the morning and evening milkings according to the experimental design. For milk composition analysis, a sample of milk from each mammary gland (from morning or from both morning and evening milkings) of approximately $100 \mathrm{~mL}$ was collected, preserved with an antimicrobial tablet (Bronopol, Broad Spectrum Micro-tabs II, D\&F Control Systems Inc., San Ramon, CA), and kept at $4^{\circ} \mathrm{C}$ until laboratory analysis, which was performed within the following $24 \mathrm{~h}$.

\section{Physicochemical Analysis}

Feed samples were analyzed for DM (ISO, 1999a), ash (ISO, 2002), and CP (ISO, 2005). Neutral detergent fiber and $\mathrm{ADF}$ were determined by the methods described by Ankom Technology (2006a,b); NDF was assayed with sodium sulfite and $\alpha$-amylase and expressed with residual ash (the latter also for ADF). The content of ether extract in the diets was determined by the Ankom filter bag technology (AOCS, 2008).

The fat, protein, TS, and lactose concentrations in milk were determined by automatic infrared spectrophotometry (ISO, 1999b) using a Milko-Scan $255 \mathrm{~A} / \mathrm{S}$ N (Foss Electric, Hillerød, Denmark). Milk SCC was carried out by a fluoro-opto-electronic technique using a Fossomatic $90 \mathrm{~A} / \mathrm{S} \mathrm{N}$ (Foss Electric).

\section{Statistical Analysis}

The weekly data of BW and DMI were analyzed by repeated-measures analysis using the MIXED procedure of SAS (SAS Inst. Inc., Cary, NC), with group being considered as the experimental unit. The statistical model included the fixed effects of antioxidant supplement treatment (control vs. supplemented), time (week), and their interaction. The group was nested within the treatment to test the effect of antioxidant supplement.

The data of milk yield of each day were averaged weekly (11 wk: 3 of period 1 and 8 of period 2). Within each experimental period (periods 1 and 2), the weekly data of milk yield and composition were analyzed by repeated-measures analysis using the above-mentioned MIXED procedure. The statistical model included the fixed effects of antioxidant supplement treatment, gland, week, and the different interactions. The antioxidant supplement effect (control vs. supplemented) was tested against ewe nested to treatment. The effects of gland (equivalent to milking frequency) and the interaction between gland and antioxidant supplement were tested against the interaction between gland and the ewe nested to treatment. The effects of week and different interactions were tested against the residual error. In all analyses, different covariance matrices were evaluated based on Schwarz's Bayesian information model fit criteria.

\section{RESULTS AND DISCUSSION}

\section{Intake and BW}

No significant differences $(P>0.10)$ attributed to the administration of the vitamin-mineral supplement were observed on intake, the mean values being $3.39 \pm 0.049$ $\mathrm{kg}$ of DM for the control group and $3.31 \pm 0.048 \mathrm{~kg}$ of DM for the supplement group. The DMI observed in the current study was within the normal range of values reported by other authors for the same breed of animals with similar physiological conditions and with rations of similar characteristics (Ramella, 2002; Bodas, 2004; Gómez-Cortés et al., 2011). The efficiency of energy utilization regarding oxygen consumption is involved in the control of intake, so animals aim at an intake 
Table 2. Effect of vitamin E plus Se supplementation and milking frequency (gland) on milk yield and composition

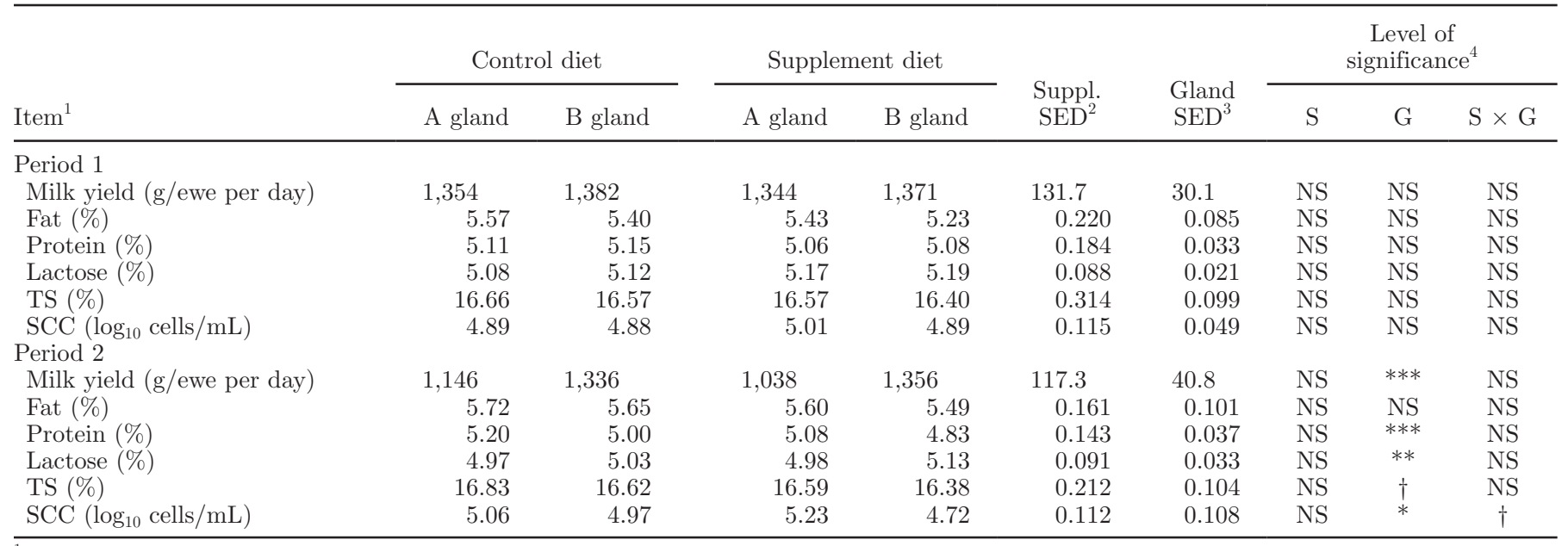

${ }^{1}$ Period 1 = both glands undergo twice-daily milking; period $2=$ A gland undergoes once-daily milking and B gland undergoes twice-daily milking.

${ }^{2}$ Standard error of the difference to compare the supplement effect.

${ }^{3}$ Standard error of the difference to compare the gland effect.

${ }^{4}$ Probability of significant effects of supplement $(\mathrm{S})$, gland $(\mathrm{G})$, and their interaction $(\mathrm{S} \times \mathrm{G})$.

$\mathrm{NS}=P>0.10 ; \dagger P<0.10{ }^{*} P<0.05 ;{ }^{* *} P<0.01 ;{ }^{* * *} P<0.001$.

level that maximizes the intake of net energy per liter of oxygen consumption (Ketelaars and Tolkamp, 1996). This theory is supported by the fact that the greater the oxygen consumption, the greater the production of reactive oxygen species; therefore, an organism tries to minimize that production in some manner. That suggests that increasing the antioxidant capacity of the organism might increase the intake capacity; however, the results observed in this study do not corroborate this theory.

Body weight increased throughout the experiment in both groups, although no significant $(P>0.10) \mathrm{BW}$ variations attributed to the effect of vitamin E-Se supplementation were found (final BW: $84.6 \pm 3.75 \mathrm{~kg}$ and $82.7 \pm 3.10 \mathrm{~kg}$ for the control and supplement group, respectively). The lack of differences in BW between animals of control and supplement groups is in agreement with the lack of observed differences in intake. It must be considered that milk yield decreased along the experimental period because of both the evolution of the lactation curve and the reduction in milking frequency in one of the glands. Hence, the nutritive requirements for milk production decreased during the course of the experiment and animals could use more dietary energy to recoup body reserves and for BW gain, accordingly.

\section{Milk Production and Composition}

The mean values corresponding to milk yield and its chemical composition, in periods 1 and 2, for each gland and experimental treatment (diet effect) are presented in Table 2.

Administration of the vitamin-mineral supplement did not have any significant influence $(P>0.10)$ on milk yield or its composition in both periods 1 and 2 ; the effect of the interaction between gland (milking frequency) and the administration of vitamin-mineral supplement was also not significant $(P>0.10)$. The interactions among these sources of variation and week were not significant $(P>0.10)$. To the best of our knowledge, no studies have tested the effect of the administration of both vitamin $\mathrm{E}$ and Se on milk yield and composition in dairy sheep. Studies have been done on supplementation of vitamin $\mathrm{E}$ and $\mathrm{Se}$ in nondeficient cattle, although the results were inconclusive. In a short-term study, Chawla and Kaur (2004) observed an increase in the milk production of cows supplemented with vitamin E, because of fewer udder infections. Smith et al. (1997) indicated that the usually observed beneficial effect of vitamin $\mathrm{E}$ and Se is indirect, by means of an improvement of the immune system and a reduction of infections in the mammary gland. However, Politis et al. (2004), Bourne et al. (2008), and Brozos et al. (2009) did not find any effect of vitamin $\mathrm{E}$ (administered alone or together with Se) on milk yield and composition in cattle. According to Yang et al. (2011), the effects of vitamin $\mathrm{E}$ and Se supplementation on milk yield and components are not unified because the optimum dose, route, and timing of vitamin $\mathrm{E}$ administration in lactating dairy cows have not been established. A recent study in dairy goats (Tufarelli and Laudadio, 
2011) showed a beneficial effect of the administration of vitamin $\mathrm{E}$ and Se on milk yield ( $7.5 \%$ increase) and fat ( $4.2 \%$ increase) and protein ( $1.3 \%$ increase) contents, which was attributed to better utilization of nutrients. Nevertheless, comparisons between studies are difficult because of differences among species.

As expected, no significant differences $(P>0.10)$ between glands in both milk yield and composition were found in period 1, when all glands were milked twice a day. However, when milking frequency was reduced from twice to once daily (period 2), differences were observed in milk yield between glands. As can be observed in Figure 1, the omission of one daily milking in one of the glands caused a significant reduction $(P$ $<0.001$ ) in milk yield compared with the gland always milked twice a day $(-14.2$ and $-23.5 \%$ in control and supplement groups, respectively). This reduction level in milk yield agrees with the findings of other authors in studies modifying the milking frequency in dairy ewes, who indicated yield decreases from 13 to 50\% (Papachristoforou et al., 1982; Knight et al., 1993; Marnet and Komara, 2008).

When milking frequency is reduced, milk accumulates in the mammary gland, exerting pressure on the alveolus epithelial cells and distorting the tight junctions. This process unleashes other processes that allow that gland to adapt itself to the new situation (Davis et al., 1999). The cisternal volume in the mammary gland is a key factor in explaining the differences in reduction of milking frequency among breeds or individuals (Davis et al., 1999; McKusick et al., 2002). In general, the greater the cisternal size, the greater the proportion of cisternal milk compared with total milk. This higher storage capacity of milk in the cistern allows the pressure exerted by accumulated milk on the alveolus epithelial cells to be reduced when extending the interval between milkings. In this study, the proportion of cisternal milk to total milk was determined before omitting one milking a day, and a nonsignificant $(P>$ $0.10)$ relationship between the reduction on milk yield (expressed as $\mathrm{kg}$ or \%) and the percentage that the cisternal milk represents was observed (Figure 2). The lack of relationship between cisternal milk percentage (indicator of the milk stock capacity) and the reduction on milk yield indicated in the present study agrees with that observed by Marnet and Komara (2008) in goats. Those authors concluded that the percentage of cisternal volume relative to total udder volume does not completely explain the individual differences in milk yield loss with long milking intervals, and suggested the different ability of the udders to accept dilatation as a possible mechanism to modulate this response; that is, the greater the elasticity of the mammary gland, the lower the intramammary pressure.

It is noteworthy that the cisternal milk percentage ranged from 50 to $75 \%$ in the present study, the mean

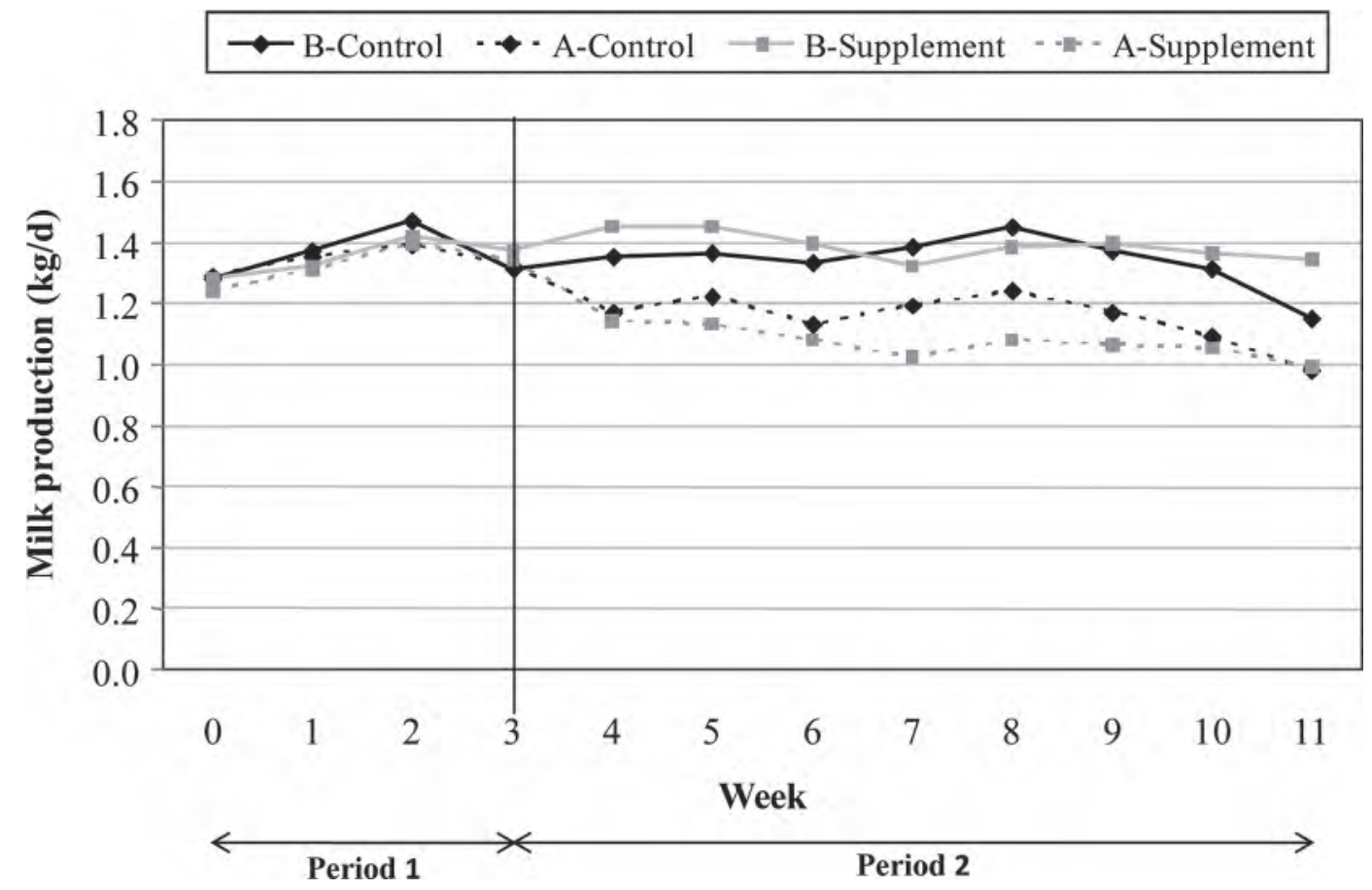

Figure 1. Milk yield for each gland (A and B) and experimental groups (control and supplement). Period $1=$ both glands undergo twicedaily milking; period $2=\mathrm{A}$ gland undergoes once-daily milking and $\mathrm{B}$ gland undergoes twice-daily milking. 


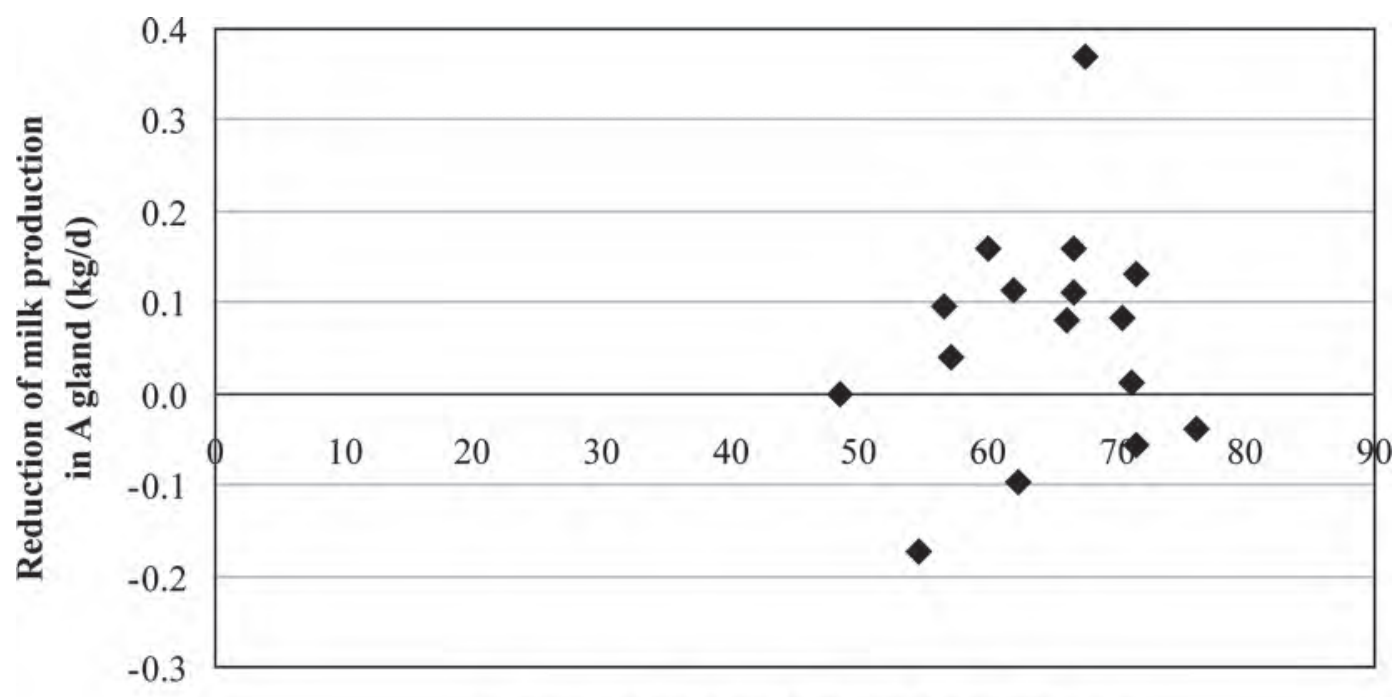

Cisternal milk/total milk in A gland (\%)

Figure 2. Relationship between milk yield reduction when increasing milking interval (data from A gland: milked once daily during period 2 ) and cisternal milk (as proportion of total milk yield).

value $(64 \%)$ being similar to that observed for Lacaune ewes (68\%; Rovai, 2001), lower than that for Sarda ewes (75\%; Marnet and McKusick, 2001), and higher than that for Manchega ewes (53\%; Rovai, 2001).

With respect to milk composition, statistically significant differences between glands were observed in period 2 . In this respect, the protein proportion increased (4.92 vs. $5.14 \% ; P<0.001)$ and the lactose proportion decreased (5.08 vs. $4.98 \% ; P=0.006)$ in milk from the gland milked once a day compared with that from the gland milked twice a day. Fat content did not vary significantly (5.57 vs. $5.66 \% ; P>0.10)$ and the difference observed between glands in TS content showed a trend to significance $(P=0.064)$, with higher values in milk coming from the gland milked once daily (16.71 vs. $16.50 \%$ ). The significant increase of both protein and TS content in the gland where one milking was omitted could be attributed, in part, to a dilution effect (less milk production). Nevertheless, the fact that we observed no significant differences in fat concentration between glands suggests that a different mechanism is in play. Stelwagen (2001) indicated that mammary gland adaptation to modifications in milking frequency is regulated by the activation of acute mechanisms such as the lactation inhibitor factor. Hence, the change in protein content could be related to modification of protein metabolism. Additionally, destabilization of tight junctions due to the increase of pressure exerted by milk accumulated in the alveolus could explain the increase in protein concentration. According to McKusick et al. (2002), increased tight junction leakiness would allow serum protein to spill over into the milk. Indeed, the lactose concentration showed the opposite behavior to that of protein, which could be attributed to the passive passage of lactose into the blood through disturbed cell junctions, thus decreasing its content in the mammary gland milk (Ben Chedly et al., 2011).

In line with our results, Nudda et al. (2002) indicated a significant increase in the percentage of milk protein in Sarda and Merino ewes (from 5.41 to 5.99\% and from 5.66 to $6.32 \%$, respectively) and no significant differences in the fat content in any breed when omitting once daily milking. Conversely, Salama et al. (2003), Hervás et al. (2006), Delamaire and GuinardFlament (2006), and Castillo et al. (2008) did not find significant variations in the protein content when extending the milking interval in goats, sheep, and cattle. Hervás et al. (2006; from 6.56 to $7.63 \%$ ), Salama et al. (2003; from 4.62 to $5.10 \%$ ), and Delamaire and Guinard-Flament (2006; from 3.93 to $4.67 \%$ ) observed that reduction in milking frequency led to significant increases in the percentage of milk fat in sheep, goats, and cattle, respectively. Moreover, Castillo et al. (2008) demonstrated that increasing the milking interval from 12 to $24 \mathrm{~h}$ in Manchega and Lacaune ewes markedly decreased milk fat content (from 8.01 to $6.97 \%$ and from 6.61 to $5.86 \%$, respectively). With regard to TS, our results agree with those of Salama et al. (2003), who reported a significant increase in TS in goats when going from 2 to 1 daily milking (from 12.9 to $13.6 \%$ ). Castillo et al. (2008) and Nudda et al. (2002) also noted significant decreases in milk lactose content when extending the milking interval from 12 to $24 \mathrm{~h}$ in Manchega and Lacaune (from 4.77 to $4.68 \%$ and from 4.76 to $4.68 \%$, 
respectively) and Merino ewes (from 4.86 to $4.61 \%$ ). However, Delamaire and Guinard-Flament (2006) and Nudda et al. (2002) did not find statistically significant differences in lactose content in cattle and Sarda ewes, respectively.

Table 3 summarizes the mean values of milk components production. We observed no significant effect $(P$ $>0.10)$ attributed to the administration of vitaminmineral supplement or gland on the production of any component in period 1. Conversely, the production of all components (fat, protein, lactose, and TS) significantly decreased $(P<0.001)$ when milking frequency was reduced (period 2). This effect was independent of the vitamin-mineral supplement administration that did not have any effect $(P>0.10)$.

\section{Milk SCC and Udder Health}

The mean value of SCC for each period, experimental treatment, and gland is shown in Table 2. Administration of the vitamin-mineral supplement did not have any significant effect $(P>0.10)$ on SCC in either experimental period. These results are in accordance with other studies showing no association between circulating vitamin E and Se levels and milk SCC in dairy cattle (Erskine et al., 1987; Jukola et al., 1996). However, Smith et al. (1997) demonstrated that the administration of a vitamin $\mathrm{E}$ and Se supplement to animals nondeficient in these nutrients exerts a protector effect on the mammary gland against infections. Politis et al. (2004) observed that high levels of vitamin E supplementation (>2,000 IU/cow per day) during the periparturient period reduced milk SCC. Differences in results may be explained by differences in species, management, the method of vitamin E supplementation (oral vs. intramuscular injection), and the level of oxidative stress.

As expected, differences in SCC between glands were not observed $(P>0.10)$ in period 1. However, significant differences $(P=0.015)$ were evident between glands in period 2, with SCC values being higher in glands milked once daily. This increase could be due both to a concentration effect as milk yield decreased during milking omission (Kamote et al., 1994) and to the impairment of the tight junction barrier, thus facilitating a paracellular influx of somatic cells into the milk without damage to the mammary secretory cells (Stelwagen and Lacy-Hulbert, 1996). Some authors did not observe a negative effect of a reduction in milkings (from 2 to 1) on SCC in studies of sheep (McKusick et al., 2002; Castillo et al., 2008; Prieto et al., 2011). In contrast, Nudda et al. (2002) reported an increase in SCC in Sarda ewes subjected to once-daily milking, and other authors observed that reducing milking frequency in dairy cattle throughout lactation (Holmes et al., 1992) or for short periods in early (Stelwagen and Lacy-Hulbert, 1996) or late (Kelly et al., 1998) lactation increased SCC. Nevertheless, it must be emphasized that the SCC found here were very low, indicating a good state of the mammary glands, and were clearly lower than those shown by other authors for milk of ewes with no mastitis (Castillo et al., 2008; Prieto et al., 2011). This agrees with the findings of Salama et al. (2003) and Hervás et al. (2006) in studies with goats and sheep, respectively, whose SCC levels were always far below that considered indicative of

Table 3. Effect of vitamin E plus Se supplementation and milking frequency on milk constituent yields

\begin{tabular}{|c|c|c|c|c|c|c|c|c|c|}
\hline \multirow[b]{2}{*}{ Item $^{1}$} & \multicolumn{2}{|c|}{ Control diet } & \multicolumn{2}{|c|}{ Supplement diet } & \multirow{2}{*}{$\begin{array}{l}\text { Suppl. } \\
\text { SED }^{2}\end{array}$} & \multirow{2}{*}{$\begin{array}{l}\text { Gland } \\
\text { SED }^{3}\end{array}$} & \multicolumn{3}{|c|}{$\begin{array}{c}\text { Level of } \\
\text { significance }\end{array}$} \\
\hline & A gland & $B$ gland & A gland & B gland & & & $\mathrm{S}$ & $\mathrm{G}$ & $\mathrm{S} \times \mathrm{G}$ \\
\hline Fat yield $(\mathrm{g} / \mathrm{d})$ & 75.8 & 74.8 & 72.7 & 71.4 & 7.76 & 1.87 & NS & NS & NS \\
\hline Protein yield $(\mathrm{g} / \mathrm{d})$ & 69.0 & 70.9 & 68.0 & 69.6 & 6.93 & 1.55 & NS & NS & NS \\
\hline Lactose yield (g/d) & 68.9 & 70.9 & 69.3 & 70.9 & 6.56 & 1.55 & NS & NS & NS \\
\hline \multicolumn{10}{|l|}{ Period 2} \\
\hline Fat yield $(\mathrm{g} / \mathrm{d})$ & 65.5 & 75.4 & 58.5 & 75.2 & 6.60 & 2.66 & NS & $* * *$ & NS \\
\hline Protein yield $(\mathrm{g} / \mathrm{d})$ & 59.5 & 66.8 & 53.4 & 65.5 & 6.69 & 1.88 & NS & $* * *$ & NS \\
\hline Lactose yield (g/d) & 57.1 & 67.4 & 51.9 & 69.3 & 6.05 & 2.22 & NS & $* * *$ & NS \\
\hline $\operatorname{TS}(\mathrm{g} / \mathrm{d})$ & 192.9 & 222.2 & 173.5 & 222.7 & 20.04 & 6.99 & NS & $* * *$ & NS \\
\hline
\end{tabular}

${ }^{1}$ Period 1 = both glands undergo twice-daily milking; period 2 = A gland undergoes once-daily milking and B gland undergoes twice-daily milking.

${ }^{2}$ Standard error of the difference to compare the supplement effect.

${ }^{3}$ Standard error of the difference to compare the gland effect.

${ }^{4}$ Probability of significant effects of supplement $(\mathrm{S})$, gland $(\mathrm{G})$, and their interaction $(\mathrm{S} \times \mathrm{G})$.

$\mathrm{NS}=P>0.10 ; * * * P<0.001$. 
possible pathologies (e.g., subclinical mastitis; Romeo et al., 1994; Marco et al., 1997), in spite of the slight increase in SCC after milking frequency reduction.

The effect of the interaction between gland and the administration of vitamin-mineral supplement on SCC showed a trend toward significance $(P=0.070)$, with the milking frequency effect being higher in the animals receiving the antioxidant supplement. This interaction highlights that the higher the SCC before increasing the milking interval, the greater the effect will be of milking omission on SCC (Kamote et al., 1994). On the other hand, the SCC increase observed when extending the milking interval was greater in the supplement group (from 4.720 to $5.233 \log _{10}$ cells $/ \mathrm{mL}$ ) than in the control group (from 4.970 to $5.058 \log _{10}$ cells $/ \mathrm{mL}$ ), which could be due to a possible adverse effect of vitamin $\mathrm{E}$ on udder health during oxidative stress mechanisms, such as reduction in milking frequency. Bouwstra et al. (2010a,b) recently observed that daily supplementation of 3,000 IU of vitamin E to dairy cattle during the dry period has an adverse effect on udder health in commercial herds with a high incidence of mastitis. According to those authors, although vitamin E has a beneficial antioxidant effect under normal physiological states, its effect can be adverse during oxidative stress processes. In our study, the dose of vitamin $\mathrm{E}$ (1,000 IU) was lower than that used for dairy cattle; nevertheless, it was still high and above requirements for sheep nutrition. Therefore, our results seem to be in accordance with those reported by Bouwstra et al. (2010a,b).

\section{CONCLUSIONS}

The reduction of milking frequency in high-yielding Assaf ewes from twice to once a day decreased milk production and lactose concentration, increased the proportion of protein and TS, and increased SCC, without any effect on the fat content. The administration of a vitamin $\mathrm{E}$ and Se supplement at the doses used in the present study did not seem to have, in the short term, a noticeable effect on the mammary gland when milking frequency was reduced. Further research is required to establish the doses of vitamin $\mathrm{E}$ and $\mathrm{Se}$ that exert a beneficial effect on the mammary gland under oxidative stress processes, and to identify the biological mechanism determining the effect associated with milking frequency and the factors that can modulate the response obtained.

\section{ACKNOWLEDGMENTS}

This work is part of a research project (Ref. PI200440E549) of the Spanish National Research Coun- cil (CSIC), Spain. N. Prieto and R. Bodas acknowledge the receipt of a research contract from the Spanish National Research Council (CSIC) and the European Social Fund under the programme JAE-Doc.

\section{REFERENCES}

Ankom Technology. 2006a. Acid detergent fiber in feeds. Filter bag technique (For A2000, A2000I). Ankom Technology Method 8. Ankom Technology Corp., Macedon, NY.

Ankom Technology. 2006b. Neutral detergent fiber in feeds. Filter bag technique (For A2000, A2000I). Ankom Technology Method 9. Ankom Technology Corp., Macedon, NY.

AOCS. 2008. Official Methods and Recommended Practices. 5th ed. American Oil Chemists' Society, Champaign, IL.

Ben Chedly, H., P. Lacasse, P. G. Marnet, M. Komara, S. Marion, and M. Boutinaud. 2011. Use of milk epithelial cells to study regulation of cell activity and apoptosis during once-daily milking in goats. Animal 5:572-579.

Bendich, A. 1990. Antioxidant micronutrients and immune responses. Ann. N. Y. Acad. Sci. 587:168-180.

Bernier-Dodier, P., L. Delbecchi, G. F. Wagner, B. G. Talbot, and P. Lacasse. 2010. Effect of milking frequency on lactation persistency and mammary gland remodeling in mid-lactation cows. J. Dairy Sci. 93:555-564.

Bodas, R. 2004. El bicarbonato de sódico en la alimentación de corderos en la etapa de crecimiento-cebo y de ovejas en lactación. PhD Thesis. Universidad de León, Spain.

Bourne, N., D. C. Wathes, K. E. Lawrence, M. McGowan, and R. A. Laven. 2008. The effect of parenteral supplementation of vitamin E with selenium on the health and productivity of dairy cattle in the UK. Vet. J. 177:381-387.

Bouwstra, R. J., M. Nielen, J. R. Newbold, E. H. J. M. Jansen, H. F. Jelinek, and T. van Werven. 2010a. Vitamin E supplementation during the dry period in dairy cattle. Part II: Oxidative stress following vitamin E supplementation may increase clinical mastitis incidence postpartum. J. Dairy Sci. 93:5696-5706.

Bouwstra, R. J., M. Nielen, J. A. Stegeman, P. Dobbelaar, J. R. Newbold, E. H. J. M. Jansen, and T. van Werven. 2010b. Vitamin E supplementation during the dry period in dairy cattle. Part I: Adverse effect on incidence of mastitis postpartum in a double-blind randomized field trial. J. Dairy Sci. 93:5684-5695.

Brozos, C. N., E. Kiossis, M. P. Georgiadis, S. Piperelis, and C. Boscos. 2009. The effect of chloride ammonium, vitamin $\mathrm{E}$ and Se supplementation throughout the dry period on the prevention of retained fetal membranes, reproductive performance and milk yield of dairy cows. Livest. Sci. 124:210-215.

Capper, J. L., R. G. Wilkinson, E. Kasapidou, S. E. Pattinson, A. M. Mackenzie, and L. A. Sinclair. 2005. The effect of dietary vitamin $\mathrm{E}$ and fatty acid supplementation of pregnant and lactating ewes on placental and mammary transfer of vitamin E to the lamb. Br. J. Nutr. 93:549-557.

Castillo, V., X. Such, G. Caja, R. Casals, E. Albanell, and A. A. K. Salama. 2008. Effect of milking interval on milk secretion and mammary tight junction permeability in dairy ewes. J. Dairy Sci. 91:2610-2619.

Chawla, R., and H. Kaur. 2004. Plasma antioxidant vitamin status of periparturient cows supplemented with $\alpha$-tocopherol and ß-carotene. Anim. Feed Sci. Technol. 114:279-285.

Davis, S. R., V. C. Farr, and K. Stelwagen. 1999. Regulation of yield loss and milk composition during once-daily milking: A review. Livest. Prod. Sci. 59:77-94.

Delamaire, E., and J. Guinard-Flament. 2006. Increasing milking intervals decreases the mammary blood flow and mammary uptake of nutrients in dairy cows. J. Dairy Sci. 89:3439-3446.

Erskine, R. J., R. J. Eberhart, L. J. Hutchinson, and R. W. Scjolz. 1987. Blood selenium concentrations and glutathione peroxidase activities in dairy herds with high and low somatic cell count. J. Am. Vet. Med. Assoc. 190:1417-1421. 
Gómez-Cortés, P. G., P. Frutos, M. A. Fuente, G. Hervás, and M. Juárez. 2011. Effects of different forage:concentrate ratios in dairy ewe diets supplemented with sunflower oil on animal performance and milk fatty acid profile. J. Dairy Sci. 94:4578-4588.

Haenlein, G. F. W. 2001. Past, present, and future perspectives of small ruminant dairy research. J. Dairy Sci. 84:2097-2115.

Haenlein, G. F. W. 2007. About the evolution of goat and sheep milk production. Small Rumin. Res. 68:3-6.

Hervás, G., J. L. Ramella, S. López, J. S. González, and A. R. Mantecón. 2006. Effect of omitting one or two milkings weekly on lactational performance in dairy ewes. J. Dairy Res. 73:207-215.

Holmes, C. W., G. F. Wilson, D. D. S. Mackenzie, and J. Purchas. 1992. The effects of milking once daily throughout lactation on performance of dairy cows grazing pasture. Proc. N.Z. Soc. Anim. Prod. 52:13-16.

ISO. 1999a. Animal feeding stuffs - Determination of moisture and other volatile matter content. Standard 6496:1999. International Organization for Standardization, Geneva, Switzerland.

ISO. 1999b. Whole milk-Determination of milkfat, protein and lactose content - Guidance on the operation of mid-infrared instruments. Standard 9622:1999. International Organization for Standardization, Geneva, Switzerland.

ISO. 2002. Animal feeding stuffs-Determination of crude ash. Standard 5984:2002. International Organization for Standardization, Geneva, Switzerland.

ISO. 2005. Animal feeding stuffs - Determination of nitrogen content and calculation of crude protein content-Part 2: Block digestion and steam distillation method. Standard 5983-2: 2005. International Organization for Standardization, Geneva, Switzerland.

Jukola, E., J. Hakkarainen, H. Saloniemi, and S. Sankari. 1996. Blood selenium, vitamin $\mathrm{E}$, vitamin $\mathrm{A}$ and beta-carotene concentrations and udder health, fertility treatments and fertility. J. Dairy Sci. 79:838-845.

Kamote, H. I., C. W. Holmes, D. D. S. Mackenzie, and R. J. Holdaway. 1994. Effects of once daily milking in later lactation on cows with either low or high initial somatic cells count. Proc. N.Z. Soc. Anim. Prod. 54:285-287.

Kelly, A. L., S. Reid, P. Joyce, J. William, and J. Foley. 1998. Effect of decreased milking frequency of cows in late lactation on milk somatic cell count, polymorphonuclear leucocyte numbers, composition and proteolytic activity. J. Dairy Res. 65:365-373.

Ketelaars, J. J., and B. J. Tolkamp. 1996. Oxigen efficiency and the control of energy flow in animals and humans. J. Anim. Sci. 74:3036-3051.

Knight, T. W., D. S. Atkinson, N. A. Haack, C. R. Palmer, and K. H. Rowland. 1993. Effects of suckling regime on lamb growth rates and milk yields of Dorset ewes. N.Z. J. Agric. Res. 36:215-222.

Lauzon, K., X. Zhao, A. Bouetard, L. Delbecchi, B. Paquette, and P. Lacasse. 2005. Antioxidants to prevent bovine neutrophil-induced mammary epithelial cell damage. J. Dairy Sci. 88:4295-4303.

Marco, J. C., M. Romeo, and A. Contreras. 1997. Udder health in dairy sheep. Pages 255-276 in Ovino de Leche: Aspectos Claves. C. Buxadé-Carbó, ed. Ediciones Mundi-Prensa, Madrid, Spain.

Marnet, P. G., and M. Komara. 2008. Management systems with extended milking intervals in ruminants regulation of production and quality of milk. J. Anim. Sci. 86:47-56.

Marnet, P. G., and B. C. McKusick. 2001. Regulation of milk ejection and milkability in small ruminants. Livest. Prod. Sci. 70:125-133.

McKusick, B. C., D. L. Thomas, Y. M. Berge, and P. G. Marnet. 2002. Effect of milking interval on alveolar versus cisternal milk accu- mulation and milk production and composition in dairy ewes. J. Dairy Sci. 85:2197-2206.

National Research Council. 1985. Nutrient Requirements of Sheep. 6th rev. ed. Natl. Acad. Sci., Washington, DC.

Nudda, A., I. R. Bencin, S. Mijatovic, and G. Pulina. 2002. The yield and composition of milk in Sarda, Awassi, and Merino sheep milked unilaterally at different frequencies. J. Dairy Sci. 85:2879-2884.

Papachristoforou, C., A. Roushias, and A. P. Mavrogenis. 1982. The effect of milking frequency on the milk production of Chios ewes and Damascus goats. Ann. Zootech. 31:37-46.

Politis, I. I. Bizelis, A. Tsiaras, and A. Baldi. 2004. Effect of vitamin E supplementation on neutrophil function, milk composition and plasmin activity in dairy cows in a commercial herd. J. Dairy Res. 71:273-278

Prieto, N., D. López, R. Bodas, S. López, A. R. Mantecón, and F. J. Giráldez. 2011. Efecto de la inclusión de aceite de girasol en la ración y de la frecuencia de ordeño sobre la producción y composición láctea en ovejas de raza Assa. Pages 231-233 in XIV Jornadas sobre Producción Animal AIDA. M. Joy, J. H. Calvo, J. Álvarez, I. Casasús, B. Panea, A. Sanz, P. Muñoz, and J. Balcells, ed. AIDA, Zaragoza, Spain.

Ramella, J. L. 2002. Producción y composición de la leche en ovejas de raza Assaf: Efecto de la duración del intervalo entre ordeños. $\mathrm{PhD}$ Thesis. Universidad de León, Spain.

Rice, D. A., and S. Kennedy. 1988. Assessment of vitamin E, selenium and polyunsaturated fatty acid interactions in the aetiology of disease in the bovine. Proc. Nutr. Soc. 47:177-184.

Rizzo, M. R., A. M. Abbatecola, M. Barbieri, M. T. Vietri, and M. Cioffi. 2008. Evidence for anti-inflammatory effects of combined administration of vitamin $\mathrm{E}$ and $\mathrm{C}$ in older persons with impaired fasting glucose: Impact on insulin action. J. Am. Coll. Nutr. $27: 505-511$

Romeo, M., A. Esnal, A. Contreras, J. Aduniz, L. González, and J. Marco. 1994. Evolution of milk somatic cell counts along the lactation period in sheep of the Latxa breed. Pages 6-9 in Int. Symp. Somatic Cells and Milk of Small Ruminants, Bella, Italy. Wageningen Pers, Wageningen, the Netherlands.

Rovai, M. 2001. Caracteres morfológicos y fisiológicos que afectan a la aptitud de ordeño mecánico en ovejas de raza Manchega y Laucane. PhD Thesis. Universidad Autónoma de Barcelona, Spain.

Salama, A. A. K., X. Such, G. Caja, M. Rovai, R. Casals, E. Albanell, M. P. Marín, and A. Martí. 2003. Effects of once versus twice daily milking throughout lactation on milk yield and milk composition in dairy goats. J. Dairy Sci. 86:1673-1680.

Smith, K. L., J. S. Hogan, and W. P. Weiss. 1997. Dietary vitamin $\mathrm{E}$ and selenium affect mastitis and milk quality. J. Anim. Sci. $75: 1659-1665$.

Stelwagen, K. 2001. Effect of milking frequency on mammary functioning and shape of the lactation curve. J. Dairy Sci. 84(E Suppl.):E204-E211.

Stelwagen, K., and J. Lacy-Hulbert. 1996. Effect of milking frequency on milk somatic cell count characteristics and mammary secretory cell damage in cows. Am. J. Vet. Res. 57:902-905.

Tufarelli, V., and V. Laudadio. 2011. Dietary supplementation with selenium and vitamin $\mathrm{E}$ improves milk yield, composition and rheological properties of dairy Jonica goats. J. Dairy Res. 78:144-148.

Yang, F., X. S. Li, and B. X. He. 2011. Effects of vitamins and traceelements supplementation on milk production in dairy cows: A review. Afr. J. Biotechnol. 10:2574-2578. 